\title{
THE ACUTE EFFECT OF THE ANTIOXIDANT DRUG U-74389G ON RED BLOOD CELL DISTRIBUTION WIDTH LEVELS DURING HYPOXIA REOXYGENATION INJURY IN RATS
}

Constantinos Tsompos ${ }^{1 *}$, Constantinos Panoulis ${ }^{2}$, Konstantinos Toutouzas ${ }^{3}$, George Zografos ${ }^{3}$, Apostolos Papalois ${ }^{4}$

${ }^{1}$ Department of Obstetrics \& Gynecology, Mesologi County Hospital, Etoloakarnania, Greece, ${ }^{2}$ Department of Obstetrics \& Gynecology, Aretaieion Hospital, ${ }^{3}$ Department of Surgery, Ippokrateion General Hospital, Athens University, Attiki, Greece, ${ }^{4}$ Exprerimental Research Center ELPEN Pharmaceuticals, Greece

\section{ЭФФЕКТИВНОСТЬ ВОЗДЕЙСТВИЯ АНТИОКСИДАНТА U-74389G НА ОТКЛОНЕНИЕ РАСПРЕДЕЛЕНИЯ ЭРИТРОЦИТОВ В МОДЕЛИ ГИПОКСИИ И РЕОКСИГЕНАЦИИ ПРИ КРЫСАХ}

Константинос Цомпос ${ }^{1 *}$, Константинос Панулис ${ }^{2}$, Константинос Тутуцас $^{3}$, Джордж Зографос ${ }^{3}$, Апостолос Папалоис ${ }^{4}$

${ }^{1}$ Отделение акушерства и гинекологии, Больнииа округа Месолонги, Этолоакарнания, Греция, ${ }^{2}$ Кафедра акушерства и гинекологии, Больница Аретеион, ${ }^{3}$ Кафедра хирургии, Больнииа Ипократеион, Афинский университет, Аттика, Греция, ${ }^{4}$ Экспериментальный исследовательский центр ЕЛПЕН Фармачевтика, Грещия

\begin{abstract}
The AIM of this experimental study was to evaluate the effect of the antioxidant drug "U-74389G" in a rat model of hypoxia reoxygenation (HR) using the previously established protocol. Effects of treatment were evaluated by mean red blood cell distribution width (RDW) levels. Materials AND METHODs: 40 rats of a mean weight of $231.875 \mathrm{~g}$ were employed in the study. RDW levels were determined at $60 \mathrm{~min}$ (groups A and C) and at $120 \mathrm{~min}$ (groups B and D) after starting the reoxygenation. Groups A and B received no drugs, whereas rats from groups $\mathrm{C}$ and D were administered with U-74389G. Results: demonstrated that U-74389G administration significantly decreased the RDW levels by $4.96 \%+2.27 \%(\mathrm{p}=0.0175)$. Reoxygenation time non-significantly decreased the RDW levels by $0.27 \%+2.41 \%(\mathrm{p}=0.8889)$. Together, $\mathrm{U}-74389 \mathrm{G}$ administration and reoxygenation time nonsignificantly decreased the RDW levels by $2.54 \%+1.39 \%(\mathrm{p}=0.0679)$. ConcLusions: $\mathrm{U}-74389 \mathrm{G}$ administration particulary in concert without reperfusion declines the RDW levels even within the short - time context of 1.5 hours reperfusion.
\end{abstract}

Key words: hypoxia, U-74389G, red blood cell distribution width, reoxygenation

Folia Medica 2015;57(3\&4):235-242

Copyright (C) 2015 Medical University, Plovdiv

\section{РЕЗЮМЕ}

ЦЕлью настоящей работы является исследование эффективности антиоксиданта U-74389G в модели гипоксии и реоксигенации с использованием протокола предыдущих исследований. Эффективность лечения была оценена путём измерения среднего отклонения распределения эритроцитов (ОРЭ). МАтериАлы и методы: Исследование проводилось на 40 крысах средним весом 231.875 g. Среднее распределение эритроцитов было измерено через 60 минут (группы А и В) и через 120 минут (группы Б и Г) после начала реоксигенации. Лекарственный продукт U-74389G ввели только животным из групп В и Г, в группах А и Б его не применяли. Результаты: Результаты показывают, что U-74389G сигнификантно понижает ОРЭ на $4.96 \%+2.27 \%(\mathrm{p}=0.0175)$. Время реоксигенации понижает ОРЭ несигнификантно на $0.27 \%+2.41 \%(\mathrm{p}=0.8889)$. В комбинации $\mathrm{U}-74389 \mathrm{G}$ и реоксигенация понижают ОРЭ несигнификантно на $2.54 \%+1.39 \%(p=0.0679)$. ЗАключЕниЕ: Применение U-74389G и особенно его взаимодействие с временем для реперфузии понижает ОРЭ, даже и за время короткой реперфузии в рамках 1.5 часа.

Ключевые слова: гипоксия, U-74389G, отклонение распределения эритроцитов, реоксигенация

Folia Medica 2015;57(3\&4):235-242

(C) 2015 Все права защищены. Медицинский университет, Пловдив

Article's history: Received: 25 Aug 2015; Received in a revised form: 11 Nov 2015; Accepted: 9 Feb 2016

*Correspondence and reprint request to: C. Tsompos, Department of Obstetrics \& Gynecology, Mesologi County Hospital, Etoloakarnania, Greece; E-mail: Constantinostsompos@yahoo.com; Tel: +302631360237 \& +306946674264 


\section{INTRODUCTION}

One of the main causes of permanent or transient damage with serious implications on adjacent organs and systems is tissue ischemia and reperfusion (IR). The use of U-74389G in IR has been a challenge for many years. However, although the progress was significant, several practical questions have not been clarified. They include: a) how potent U-74389G should be b) when it should be administered and c) in which optimal dose U-74389G should be administered. The promising effect of U-74389G in tissue protection has been noted in several IR studies. U-74389G, or also known as 21-[4-(2,6-di1-pyrrolidinyl-4-pyrimidinyl)-1-piperazinyl]-pregna$1,4,9(11)$-triene-3,20-dione maleate salt, is an antioxidant which prevents both arachidonic acid-induced and iron-dependent lipid peroxidation. ${ }^{1}$ It protects against IR injury in animal heart, liver and kidney models. These membrane-associating antioxidants are particularly effective in preventing permeability changes in brain microvascular endothelial cells monolayers. ${ }^{2}$ Lazaroids, a novel series of glucocorticoid compounds 21-aminosteroids, have the properties of free radical scavenging. U-74389G is one of the 132 similar lazaroid compounds. It has a molecular weight of $726.90406 \mathrm{~g} / \mathrm{mol}$; it has a selective action on vascular endothelium with vitamin E-like properties. The most famous activity is that of neuroprotective and membrane-stabilizing properties. Although it accumulates in the cell membrane thus protecting vascular endothelium from peroxidative damage, it hardly penetrates the blood-brain barrier. More specifically, Hori $\mathrm{H}$ et al. $^{3}$ showed its excellent effect on central nervous system trauma and ischemia. The degree of elevation of action potential thresholds and the rate of missing outer hair cells were significantly reduced demonstrating that U-74389G has a protective effect on cisplatininduced ototoxicity without glucocorticoid action. Schmid-Elsaesser R et al. ${ }^{4}$ showed significantly less neurologic deficits postoperatively and significantly reduced cortical infarct volumes by the neuroprotective microvascularly acting 21-aminosteroid U74389G. Passaquin AC et al. ${ }^{5}$ elicited a beneficial effect of glucocorticoids in Duchenne muscular dystrophy, attributing it to a reduction of the pathological increase in $\mathrm{Ca}^{++}$influx via an effect on the sarcolemma of $\mathrm{C} 2 \mathrm{C} 12$ skeletal muscle cells. Van

Table 1. The U-74389G influence $\left( \pm \mathrm{SD}\right.$ ) on the levels of some seric variables ${ }^{15}$ concerning reperfusion (rep) time

\begin{tabular}{|c|c|c|c|c|c|c|c|c|}
\hline Variable & 1h rep & p-value & 1.5h rep & p-value & $2 \mathrm{~h}$ rep & p-value & $\begin{array}{l}\text { interaction of } \\
\text { U-74389G } \\
\text { and rep }\end{array}$ & p-value \\
\hline $\mathrm{RBC}$ & $+1.39 \% \pm 0.71 \%$ & 0.7161 & $+0.64 \% \pm 0.32 \%$ & 0.8106 & $-0.10 \% \pm 0.05 \%$ & 0.9762 & $+1.05 \% \pm 0.53 \%$ & 0.4911 \\
\hline Hemoglobin & $+5.2 \% \pm 2.8 \%$ & 0.0925 & $+3.9 \% \pm 2.1 \%$ & 0.0604 & $+2.7 \% \pm 3.2 \%$ & 0.3544 & $+2.5 \% \pm 1.3 \%$ & 0.0423 \\
\hline $\begin{array}{l}\text { Mean corpuscu- } \\
\text { lar hemoglobin }\end{array}$ & $+1.77 \% \pm 0.96 \%$ & 0.0663 & $+2.40 \% \pm 0.57 \%$ & 0.0001 & $+3.03 \%+0.71 \%$ & 0.0003 & $1.33 \%+0.36 \%$ & 0.0005 \\
\hline Platelet-crit ${ }^{16}$ & $+3.80 \% \pm 9.87 \%$ & 0.6373 & $+9.23 \% \pm 6.29 \%$ & 0.1064 & $+14.66 \% \pm 9.03 \%$ & 0.0833 & $+6.72 \% \pm 3.73 \%$ & 0.0712 \\
\hline Glucose & $-6.41 \% \pm 3.50 \%$ & 0.0663 & $-8.57 \% \pm 2.06 \%$ & 0.0001 & $-10.74 \% \pm 2.52 \%$ & 0.0003 & $-4.76 \% \pm 1.28 \%$ & 0.0005 \\
\hline Total protein & $-5.48 \% \pm 2.99 \%$ & 0.0663 & $-7.34 \% \pm 1.76 \%$ & 0.0000 & $-9.20 \% \pm 2.16 \%$ & 0.0000 & $-4.08 \% \pm 1.10 \%$ & 0.0000 \\
\hline $\begin{array}{l}\text { Alkaline phos- } \\
\text { phatase }\end{array}$ & $+22.66 \% \pm 12.37 \%$ & 0.0663 & $+31.91 \% \pm 7.69 \%$ & 0.0001 & $+41.16 \% \pm 9.65 \%$ & 0.0003 & $+17.75 \% \pm 4.79 \%$ & 0.0005 \\
\hline $\begin{array}{l}\text { Creatine }^{17} \text { phos- } \\
\text { phokinas }\end{array}$ & $+54.32 \% \pm 13.75 \%$ & 0.0012 & $+35.34 \% \pm 17.20 \%$ & 0.0260 & $+16.37 \% \pm 30.24 \%$ & 0.4951 & $+18.52 \% \pm 9.44 \%$ & 0.0770 \\
\hline Sodium & $+1.22 \% \pm 0.66 \%$ & 0.0707 & $+0.17 \% \pm 0.61 \%$ & 0.7714 & $-0.87 \% \pm 1.03 \%$ & 0.3995 & $-0.32 \% \pm 0.36 \%$ & 0.3693 \\
\hline Chloride & $-0.58 \% \pm 0.77 \%$ & 0.4533 & $-0.97 \% \pm 0.53 \%$ & 0.0879 & $-1.36 \% \pm 0.76 \%$ & 0.1113 & $-0.75 \% \pm 0.38 \%$ & 0.0159 \\
\hline Calcium & $0 \% \pm 1.75 \%$ & 1 & $-0.14 \% \pm 1.10 \%$ & 0.8782 & $-0.28 \% \pm 1.54 \%$ & 0.8492 & $+0.14 \% \pm 0.64 \%$ & 0.8245 \\
\hline Phosphorus & $-2.23 \% \pm 5.51 \%$ & 0.7966 & $-1.61 \% \pm 3.32 \%$ & 0.5789 & $-1 \% \pm 4.48 \%$ & 0.8129 & $-1.09 \% \pm 2 \%$ & 0.5771 \\
\hline Magnesium & $+1.33 \% \pm 3.59 \%$ & 0.7033 & $-0.28 \% \pm 2.75 \%$ & 0.9171 & $-1.90 \% \pm 5.28 \%$ & 0.7161 & $+0.36 \% \pm 4.58 \%$ & 0.8228 \\
\hline Mean & $+5.92 \% \pm 16.16 \%$ & 0.3643 & $+4.97 \% \pm 13.48 \%$ & 0.3259 & $+4.03 \% \pm 13.50 \%$ & 0.3691 & $+2.87 \% \pm 7.33 \%$ & 0.2532 \\
\hline
\end{tabular}


Klaveren $\mathrm{Rj}$ et al. ${ }^{6}$ supposed that direct inactivation of the membrane-bound $\gamma \mathrm{GT}$ by hyperoxia is the most likely mechanism for the increased $\gamma \mathrm{GT}$, SOD, and GSH levels in oxygen-exposed cells by U-74389G. Schmid-Elsaesser R et al. ${ }^{7}$ concluded that antioxidative compounds which cross the blood-brain barrier are more effective in focal cerebral ischemia than agents which predominantly act on the endothelium of cerebral microvessels. Lehmann $\mathrm{C}$ et $\mathrm{al}^{8}{ }^{8}$ decreased $\mathrm{TNF}_{\alpha}$ release during endotoxemia permitting treatment of septic states. As immunosuppressant it may act through activation of T-cells or by inhibiting the activation of helper cells. While immunosuppression primarily prevents rejection of transplanted organs, new applications involving mediation of the effects of interleukins and other cytokines are emerging. Lehmann $\mathrm{C}$ et al. ${ }^{9}$ attenuated leukocyte adherence and their rolling behavior in intestinal venules which is found increased during endotoxemia. Horáková $\mathrm{L}$ et al. ${ }^{10}$ calculated the preventive effect concerning lipid peroxidation at $160 \mathrm{IC} 50 \mu \mathrm{mol} / 1$ by $\mathrm{U} 74389 \mathrm{G}$ in oxidative stress. Heim $\mathrm{C}$ et al. ${ }^{11}$ totally prevented the learning impairments, suggesting that lipid peroxidation may be responsible for the late learning deficiencies. Vlkolinský $\mathrm{R}^{12}$ revealed protective activity on synaptic transmission (ST) recovery and on $t_{1 / 2}$ during hypoxia; a protective potency of U-74389G on population spikes (PoS) recovery and a possibility to delay the early ST decay during hypoxia, which might indicate improved energetic state of neurons in the treated tissue. Durmaz R et al. ${ }^{13}$ showed antiproliferative properties on cancer cells calculating an IC50 value at $91 \mathrm{~m} \mathrm{mM}$. Kondziolka D et al. ${ }^{14}$ prevented regional edema favoring radiosurgery, surrounding brain protection without reducing the desired therapeutic effect. A meta-analysis of 13 published seric variables coming from the same experimental setting, tried to provide a numeric evaluation of the U-74389G efficacy at the same endpoints (Table 1). Several publications

Table 2. Weight and RDW levels addressed trials of other similar antioxidant molecules to which the studied molecule U-74389G belongs.

\section{AIM}

The aim of this experimental study was to evaluate the effect of U-74389G in a rat model of hypoxia - reoxygenation (HR) using mean red blood cell distribution width (RDW) levels.

\section{MATERIALS AND METHODS}

ANIMAL PREPARATION

This basic experimental research was licensed by Veterinary Address of East Attiki Prefecture under 3693/12-11- 2010 \& 14/10-1-2012 decisions. All required settings including consumables, equipment and substances used, were a grant of Experimental Research Center of ELPEN Pharmaceuticals Co. Inc. S.A. at Pikermi, Attiki. Accepted standards of humane animal care were adopted for Albino female Wistar rats. Normal housing included continuous access to food and water in laboratory 7 days before the experiment. The experiment was acute, this is, awakening and preservation of animals was not following the experiment. Rats were randomly delivered to four experimental groups by 10 animals in each one, using following protocols of HR: hypoxia for $45 \mathrm{~min}$ followed by reoxygenation for $60 \mathrm{~min}$ (group A); hypoxia for $45 \mathrm{~min}$ followed by reoxygenation for $120 \mathrm{~min}$ (group B); hypoxia for 45 min followed by immediate U-74389G intravenous (IV) administration and reoxygenation for $60 \mathrm{~min}$ (group C); hypoxia for 45 min followed by immediate $\mathrm{U}-74389 \mathrm{G}$ IV administration and reoxygenation for $120 \mathrm{~min}$ (group D). The dose of U-74389G was $10 \mathrm{mg} / \mathrm{kg}$ body mass of animals.

Prenarcosis preceded general anesthesia. The detailed anesthesiologic technique is described in related references. ${ }^{15-17}$ Oxygen supply, electrocardiogram and acidometry were continuously provided during whole experiment performance. The protocol of HR was followed.

\begin{tabular}{cccc}
\hline Groups & Variable & Mean & Std. Dev \\
\hline A & Weight & $243.0 \mathrm{~g}$ & $45.8 \mathrm{~g}$ \\
& RDW & $11.42 \%$ & $1.081974 \%$ \\
\hline $\mathrm{B}$ & Weight & $262.0 \mathrm{~g}$ & $31.1 \mathrm{~g}$ \\
& RDW & $11.26 \%$ & $0.7515908 \%$ \\
\hline $\mathrm{C}$ & Weight & $212.5 \mathrm{~g}$ & $17.8 \mathrm{~g}$ \\
& RDW & $10.74 \%$ & $0.566078 \%$ \\
\hline $\mathrm{D}$ & Weight & $210.0 \mathrm{~g}$ & $18.1 \mathrm{~g}$ \\
& RDW & $10.84 \%$ & $0.6653319 \%$ \\
\hline
\end{tabular}


Hypoxia was caused by clamping inferior aorta over renal arteries with forceps for $45 \mathrm{~min}$ after laparotomic access had been achieved. Reoxygenation was induced by removing the clamp and reestablishment of inferior aorta patency. After exclusion of a blood flow, the protocol of HR was applied as described above for each experimental group. U-74389G was administered at the time of reoxygenation; through inferior vena cava after the catheterization had been achieved. The RDW levels were determined at 60th min of reoxygenation (for $\mathrm{A}$ and $\mathrm{C}$ groups) and at 120th min of reoxygenation (for B and D groups). Forty female Wistar albino rats were used (mean weight 231.875 g [Std. Dev: $36.59703 \mathrm{~g}$ ], with minimum weight $165 \mathrm{~g}$ and maximum weight $320 \mathrm{~g}$. Rats' weight could be potentially a confusing factor, e.g. more obese rats to have higher or lower RDW levels. This suspicion was also investigated.

\section{CONTROL GROUPS}

20 control rats (mean mass 252.5 g [Std. Dev: $39.31988 \mathrm{~g}]$ ) suffered by hypoxemia for $45 \mathrm{~min}$ followed by reoxygenation.

\section{Group $A$}

Reoxygenation lasted for $60 \mathrm{~min}(\mathrm{n}=10$ controls rats) mean mass $243 \mathrm{~g}$ [Std. Dev: $45.77724 \mathrm{~g}$ ], mean RDW levels $11.42 \%$ [Std. Dev: 1.081974\%] (Table 2).

\section{Group B}

Reoxygenation lasted for $120 \mathrm{~min}(\mathrm{n}=10$ controls rats) mean mass $262 \mathrm{~g}$ [Std. Dev: $31.10913 \mathrm{~g}$ ], mean RDW levels 11.26 \% [Std. Dev: 0.7515908\%] (Table 2).

\section{Lazaroid (L) group}

$20 \mathrm{~L}$ rats (mean mass $211.25 \mathrm{~g}$ [Std. Dev: $17.53755 \mathrm{~g}$ ] suffered hypoxemia for $45 \mathrm{~min}$ followed by reoxygenation in the beginning of which $10 \mathrm{mg}$ U-74389G/kg body weight were IV administered. Group C

Reoxygenation lasted for $60 \min (n=10 L$ rats) mean mass $212.5 \mathrm{~g}$ [Std. Dev: $17.83411 \mathrm{~g}$ ], mean RDW levels $10.74 \%$ [Std. Dev: 0.566078\%] (Table 2).

\section{Group D}

Reoxygenation lasted for $120 \min (n=10 \mathrm{~L}$ rats) mean mass $210 \mathrm{~g}$ [Std. Dev: $18.10463 \mathrm{~g}$ ], mean RDW levels 10.84 \% [Std. Dev: 0.6653319\%] (Table 2).

\section{RESULTS}

Rats of each group were compared by weight and RDW level with each other by statistical paired t-tests (Table 3). Any significant difference among RDW levels was investigated whether owed in potent significant weight correlations. Applying generalized linear models (glm) with dependant variable the RDW levels and independent variables the U-74389G or no drug, the reperfusion time and both variables in combination resulted in following: U-74389G administration possessed a trend to significantly decrease the RDW levels by $0.55 \%$ [-1.044414\% - -0.0555861\%] $(\mathrm{P}=0.0302)$.

Table 3. Statistical significance of mean values difference for groups (DG) after statistical paired t test application

\begin{tabular}{cccc}
\hline DG & Variable & Difference & p-value \\
\hline A-B & Weight & $-19 \mathrm{~g}$ & 0.3555 \\
& RDW & $0.16 \%$ & 0.6299 \\
\hline A-C & Weight & $30.5 \mathrm{~g}$ & 0.0674 \\
& RDW & $0.68 \%$ & 0.0383 \\
\hline A-D & Weight & $33 \mathrm{~g}$ & 0.0574 \\
& RDW & $0.58 \%$ & 0.0969 \\
\hline B-C & Weight & $49.5 \mathrm{~g}$ & 0.0062 \\
& RDW & $0.52 \%$ & 0.0465 \\
\hline B-D & Weight & $52 \mathrm{~g}$ & 0.0009 \\
& RDW & $0.42 \%$ & 0.0743 \\
\hline C-D & Weight & $2.5 \mathrm{~g}$ & 0.7043 \\
& RDW & $-0.1 \%$ & 0.5751 \\
\hline
\end{tabular}

Table 4. The decreasing influence of U-74389G in connection with reperfusion time

\begin{tabular}{ccccc}
\hline \multirow{2}{*}{ Decrease } & 95\% c. in. & \multirow{2}{*}{ Reperfusion time } & \multicolumn{2}{c}{ p-values } \\
\cline { 4 - 5 } & $-1.491269 \%-0.1312691 \%$ & $1 \mathrm{~h}$ & 0.0383 & 0.0952 \\
$0.68 \%$ & $-1.044414 \%--0.0555861 \%$ & $1.5 \mathrm{~h}$ & 0.0048 & 0.0302 \\
$0.55 \%$ & $-1.086875 \%-0.2468748 \%$ & $2 \mathrm{~h}$ & 0.0743 & 0.2023 \\
$0.42 \%$ & $-0.556281 \%-0.4962809 \%$ & reoxygenation time & 0.8691 & 0.9087 \\
$0.03 \%$ & $-0.5854412 \%-0.0218048 \%$ & interaction & & 0.0679 \\
$0.2818182 \%$ & &
\end{tabular}


Table 5. The (\%) decreasing influence of U-74389G in connection with reperfusion time.

\begin{tabular}{cccc}
\hline Decrease & \pm SD & Reperfusion time & p-values \\
\hline $6.13 \%$ & $\pm 3.73 \%$ & $1 \mathrm{~h}$ & 0.0667 \\
$4.96 \%$ & $\pm 2.27 \%$ & $1.5 \mathrm{~h}$ & 0.0175 \\
$3.80 \%$ & $\pm 3.07 \%$ & $2 \mathrm{~h}$ & 0.1383 \\
$0.27 \%$ & $\pm 2.41 \%$ & reoxygenation time & 0.8889 \\
$2.54 \%$ & $\pm 1.39 \%$ & interaction & 0.0679 \\
\hline
\end{tabular}

This finding was crepant with the results of paired t-test $(\mathrm{p}=0.0048)$. Reoxygenation time nonsignificantly decreased the RDW levels by $0.03 \%$ $[-0.556281 \%-0.4962809 \%](\mathrm{P}=0.9087)$, also in accordance with paired t-test $(\mathrm{p}=0.8691)$. However, U-74389G administration and reoxygenation time in combination non-significantly decreased the RDW levels by $0.2818182 \%$ [-0.5854412\% $0.0218048 \%$ ] $(\mathrm{P}=0.0679)$. The above and Table 3 are summed in Tables 4 and 5. Considering the masses of the animals as independent variable at glm, a non-significant association with RDW levels was revealed $(p=0.3928)$, suggesting that further investigation was not needed.

\section{DISCUSSION}

Salvagno GL et a ${ }^{18}$ describe red blood cell distribution width (RDW) as a simple and inexpensive parameter, which reflects the degree of heterogeneity of erythrocyte volume (conventionally known as anisocytosis); which is traditionally used in laboratory hematology for differential diagnosis of anemias. Nonetheless, recent evidence attests that anisocytosis is commonplace in human disorders such as cardiovascular disease, venous thromboembolism, cancer, diabetes, community-acquired pneumonia, chronic obstructive pulmonary disease, liver and kidney failure, as well as in other acute or chronic conditions. Even more importantly, the value of RDW is now being regarded as a strong and independent risk factor for death in the general population. An increased RDW mirrors a profound deregulation of erythrocyte homeostasis involving both impaired erythropoiesis and abnormal red blood cell survival, which may be attributed to a variety of underlying metabolic abnormalities such as shortening of telomere length, oxidative stress, inflammation, poor nutritional status, dyslipidemia, hypertension, erythrocyte fragmentation and alteration of erythropoietin function.

The following situations show how hypoxia can influence RDW levels. Shrestha $\mathrm{K}$ et $\mathrm{al}^{19}$ noticed neutrophil gelatinase-associated lipocalin (NGAL), an iron-regulatory glycoprotein, to be upregulated systemically in response to ischemia. Plasma NGAL levels were inversely correlated with indices of anemia including RDW levels $(\mathrm{P}=.007)$ independent of underlying oxidant stress and estimated myeloperoxidase levels $(\mathrm{P}=.045)$. Isik $\mathrm{T}$ et al. ${ }^{20}$ have shown RDW levels as an independent correlate predictor index of adverse outcomes also associated with both presence and severity of isolated ischemia than baseline RDW levels measured at ischemic patients and controls.

Sharp J et al..$^{21}$ considered mitochondrial dysfunction as a fundamental abnormality in the vascular endothelium and smooth muscle of patients with pulmonary arterial hypertension (PAH). Coenzyme $\mathrm{Q}(\mathrm{CoQ})$ is essential for mitochondrial function and efficient oxygen utilization as the electron carrier in the inner mitochondrial membrane. PAH patients had higher CoQ levels than controls with supplementation, and a tendency to a higher reduced-tooxidized CoQ ratio. Cardiac parameters, hemoglobin and red cell maturation were improved and red cell distribution width (RDW) was decreased in PAH patients with CoQ supplementation, consistent with improved mitochondrial synthetic function. Bujak $\mathrm{K}$ et al. ${ }^{22}$ included coronary artery disease (CAD) in the importance of RDW as a predictor of poor clinical outcomes in the settings of various diseases. The negative prognostic effects of elevated RDW levels may be attributed to the adverse effects of independent risk factors such as inflammation, oxidative stress, and vitamin $\mathrm{D}_{3}$ and iron deficiency on bone marrow function (erythropoiesis). Elevated RDW values may reflect the intensity of these phenomena and their unfavorable impacts on bone marrow erythropoiesis. Furthermore, decreased red blood cell deformability among patients with higher RDW values impairs blood flow through the microcirculation, resulting in the diminution of oxygen supply at the tissue level, particularly among patients suffering from myocardial infarction. Malik A et $\mathrm{al}^{23}$ named eryptosis in analogy to apoptosis, the suicidal death of erythrocytes which involves cell shrinkage and cell membrane scrambling with phosphatidylserine translocation to the erythrocyte surface. Triggers of eryptosis include oxidative stress, increase of cytosolic $\mathrm{Ca}^{++}$activity $\left(\left[\mathrm{Ca}^{++}\right]_{\mathrm{i}}\right)$, and ceramide. Phospholipid scrambling of the erythrocyte cell membrane is stimulated at least partially by the induction of oxidative stress, increase of $\left[\mathrm{Ca}^{++}\right]_{i}$ and up-regulation of 
ceramide abundance. Despite increases of $\left[\mathrm{Ca}^{++}\right.$ ]$_{\mathrm{i}}$ and cell volumes, RWD were slightly reduced. Dong $\mathrm{X}$ et al. ${ }^{24}$ proposed chronic inflammation as a candidate mechanism between benign prostatic hyperplasia (BPH) and metabolic syndrome (MetS). MetS was diagnosed in $34 \%$ of $\mathrm{BPH}$ patients. The RDW values were found to be higher in the BPH group than in the control group by $0.7 \pm 0.8[\mathrm{P}<$ $0.001]$. There was a significant correlation between RDW and total prostate volume (TPV) $(r=0.370$, $\mathrm{P}<0.001)$, body mass index (BMI) $(\mathrm{r}=0.367$, $\mathrm{P}<0.001)$ and MetS $(\mathrm{r}=0.276, \mathrm{P}<0.001)$. The RDW level is significantly higher in patients with BPH than that in control and independent predictor of MetS in BPH patients. Yilmaz Ö et al. $^{25}$ associated high levels of RDW with oxidative stress and cardiovascular disease risk. RDW levels were significantly higher in the polycystic ovary syndrome (PCOS) group than in control group by $0.39 \pm 0.88 \%(p=0.004)$. RDW levels were positively correlated with hs-CRP, HOMA-IR and BMI. RDW levels were useful as a diagnostic marker for PCOS, finding an optimal cut-off value for detecting PCOS was $\geq 12.54 \%$ (sensitivity $67 \%$ and specificity 70\%). Subjects above this cut-off value were nearly 2.8 times more likely to develop PCOS than subjects under it. This link between RDW and PCOS may be due to an underlying chronic inflammation in subjects with PCOS. Dada OA et al. ${ }^{26}$ considered chronic inflammation and increased levels of oxidative stress as telltale signs of type 2 diabetics. The mean RDW $\pm \mathrm{SD}$ was higher in the diabetics by $0.4 \pm 3.91 \mathrm{fl}$ than in the controls. The mean RDW-CV (RDW coefficient of variation) was $0.06+1.32 \%$ for diabetics, higher than in controls finding a statistically significant positive correlation between the RDW-CV and blood pressure in the diabetics. Lorente L et al. ${ }^{27}$ found higher values of red blood cell distribution width (RDW) in non-surviving than in surviving septic patients. RDW predicted and was associated with 30 -day mortality at the first 8 days $(p=0.03)$. RDW showed a positive correlation with serum MDA levels until day 4, with serum TNF- $\alpha$ levels and SOFA score until day 8 . Non-surviving septic patients showed persistently higher RDW during the first week of ICU stay than survivors. RDW during the first week was associated with sepsis severity and mortality; it could also be used as biomarker of outcome in septic patients. Tosu AR et al. ${ }^{28}$ found that increased RDW levels are significantly higher in non-dipper HT hypertension (NDHT) patients than dipper HT patients and control group $(\mathrm{p}<$
0.05). Tsuboi $\mathrm{S}$ et al. ${ }^{29}$ consider red blood cell distribution width (RDW) that reflects oxidative stress and chronic inflammation in patients with cardiovascular disease. Diabetes mellitus increases oxidative stress and vascular inflammation, which accelerate atherosclerosis. Patients with high RDW $[14.0 \%]$ were more likely to be older, show dyslipidemia and have a lower ejection fraction and decreased hemoglobin level than patients with low RDW [12.6\%]. The cumulative incidence of all-cause death [mortality] was significantly higher in the high RDW group than in the low RDW group (log-rank $\mathrm{P}=0.0015$ ) in diabetic patients after elective percutaneous coronary intervention (PCI). Roy $\mathrm{CN}$ et al. ${ }^{30}$ assessed elevated plasma carboxymethyl-lysine (CML) and low plasma selenium [biomarkers of oxidative stress] as longterm independent predictors of anemia in older community-dwelling adults after adjustment also for red blood cell distribution width. These findings support the idea that oxidative stress contributes to the development of anemia.

Redox plays a general role in RDW levels as following examples show: Karakilcik AZ et al. ${ }^{31}$ claim that exercise may enhance oxidative stress. Antioxidants can efficiently scavenge ROS before they initiate oxidative damage of biomolecules such as enzymes, nucleic acids, lipids and lipoproteins in the body. The cholesterol and low density lipoprotein-cholesterol (LDL-C), red blood cell distribution width (RDW) and TBARS levels were significantly decreased $(\mathrm{P}<0.05)$ with exercise plus vitamin $\mathrm{C}$. There were significant correlations $(\mathrm{P}<0.05$ to $\mathrm{P}<$ $0.01)$ between lipid values and erythrocyte indices. In addition, exercise plus vitamin $\mathrm{C}$ may diminish TBARS-levels and may affect the values of RDW in young soccer players. Ribeiro IF et al. ${ }^{32}$ investigated the influence of erythropoietin $(\mathrm{EPO} T \rightarrow \mathrm{G})$ and $\alpha$-actinin-3 (ACTN3 R577X) polymorphisms on plasma lipid peroxidation and hemogram. Both polymorphisms influenced the runners' response to pequi oil: significant responses were observed for the EPO TT and TG genotypes in red blood cell distribution width values. These results emphasize the importance of studying nutrigenomic effects on athletes' performance. Prasad K considers ${ }^{33}$ that hypercholesterolemia induces oxidative stress, which is known to have adverse effects on the integrity of cells. Hence, hypercholesterolemia may have adverse effects on the hemopoietic system. The results show that hypercholesterolemia increased RDW levels.

The assumption is whether $\mathrm{U}-74389 \mathrm{G}$ among and 
besides its above mentioned protective context on ototoxicity and central nervous system; in Duchenne muscular dystrophy; at inactivation of membranebound enzymes; on septic states; on endotoxemia; on learning impairments and at antiproliferative properties, has any possible effects also on acute hemopoiesis. The results of this study are very encouraging concerning RDW. There appears a current undiminished interest in the identification of such a capacity that could urgently decline the RDW levels providing a beneficial decline for negative prognostic prospect in internal medicine.

\section{CONCLUSIONS}

U-74389G administration and particularly its interaction with reperfusion time significantly declines the RDW levels favoring the prognostic effect in internal medicine.

\section{ACKNOWLEDGMENT}

This study was funded by Scholarship by the Experimental Research Center ELPEN Pharmaceuticals (E.R.C.E), Athens, Greece. The research facilities for this project were provided by the aforementioned institution.

\section{REFERENCES}

1. https://www.caymanchem.com/app/template/Product.vm/catalog/75860.

2. Fenglin Shi, Jennifer Cavitt, Kenneth L Audus. 21-aminosteroid and 2-(aminomethyl)chromans inhibition of arachidonic acid-induced lipid peroxidation and permeability enhancement in bovine brain microvessel endothelial cell monolayers. Free Radical Biology and Medicine, 19(3), 349-357 (1995).

3. Hori H, Kanno H. An experimental study of the protective effect of lazaroid (U-74389G) on cisplatininduced toxicity. Nihon Jibiinkoka Gakkai Kaiho 1999 Jan;102(1):8-18.

4. Schmid-Elsaesser R, Hungerhuber E, Zausinger S, Baethmann A, Reulen HJ. Neuroprotective efficacy of combination therapy with two different antioxidants in rats subjected to transient focal ischemia. Brain Res 1999 Jan 23;816(2):471-9.

5. Passaquin AC, Lhote P, Rüegg UT. Calcium influx inhibition by steroids and analogs in $\mathrm{C} 2 \mathrm{C} 12$ skeletal muscle cells. Br J Pharmacol 1998 Aug; 124(8):1751-9.

6. van Klaveren RJ, Pype JL, Demedts M, Nemery B. Decrease in gamma-glutamyltransferase activity in rat type II cells exposed in vitro to hyperoxia: effects of the 21-aminosteroid U-74389G. Exp Lung Res 1997 Jul-Aug;23(4):347-59.

7. Schmid-Elsaesser R, Zausinger S, Hungerhaber
E, Baethmann A, Reulen HJ. Neuroprotective properties of a novel antioxidant (U-101033E) with improved blood-brain barrier permeability in focal cerebral ischemia. Acta Neurochir Suppl. 1997;70:176-8.

8. Lehmann C, Egerer K, Georgiew A, Weber M, Grune T, Kox WJ. Inhibition of tumor necrosis factor-alpha release in rat experimental endotoxemia by treatment with the 21-aminosteroid U-74389G. Crit Care Med 1999 Jun;27(6):1164-7.

9. Lehmann C, Georgiew A, Weber M, Birnbaum J, Kox WJ. Reduction in intestinal leukocyte adherence in rat experimental endotoxemia by treatment with the 21-aminosteroid U-74389G. Intensive Care Med 2001 Jan;27(1):258-63.

10.Horáková L, Ondrejicková O, Bachratá K, Vajdová M. Preventive effect of several antioxidants after oxidative stress on rat brain homogenates. Gen Physiol Biophys 2000 Jun;19(2):195-205.

11. Heim C, Kolasiewicz W, Sontag KH. The effects of the 21-aminosteroid U-74389G on spatial orientation in rats after a cerebral oligemic episode and ironinduced oxidative stress. J Neural Transm (Vienna) 2000;107(1):95-104.

12. Vlkolinský R, Stolc S. Effects of stobadine, melatonin, and other antioxidants on hypoxia/reoxygenation-induced synaptic transmission failure in rat hippocampal slices. Brain Res 1999 Dec 11;850(12):118-26.

13. Durmaz R, Deliorman S, Isiksoy S, Uyar R, Erol K, Tel E. Antiproliferative properties of the lazaroids U-83836E and U-74389G on glioma cells in vitro. Pathol Oncol Res 1999;5(3):223-8.

14. Kondziolka D, Somaza S, Martinez AJ, Jacobsohn J, Maitz A, Lunsford LD, Flickinger JC. Radioprotective effects of the 21-aminosteroid U-74389G for stereotactic radiosurgery. Neurosurgery. 1997 Jul;41(1):203-8.

15.Tsompos C, Panoulis C, Toutouzas K, Zografos G, Papalois A. The Effect of the Antioxidant Drug U-74389G on Magnesium Levels During HypoxiaReoxygenation Injury in Rats. Annals of the Russian Academy of Medical Sciences. 2015; 70 (4): 408-412. Doi: 10.15690/vramn.v70.i4.1405.

16. Tsompos C, Panoulis C, Toutouzas K, Zografos G, Papalois A. The acute effect of the antioxidant drug "U-74389G" on platelet-crit levels during hypoxia reoxygenation injury in rats. Acta Phlebologica 2015 August;16(2):77-81.

17.C. Tsompos, C. Panoulis, K. Toutouzas, G. Zografos, A. Papalois. The Effect of the Antioxidant Drug "U74389G" on Creatine Phosphokinase Levels during Ischemia Reperfusion Injury in Rats. Erciyes Med J 2015; 37(3): 91-7.

18. Salvagno GL, Sanchis-Gomar F, Picanza A, Lippi 
G. Red blood cell distribution width: A simple parameter with multiple clinical applications. Crit Rev Clin Lab Sci 2015 Apr;52(2):86-105.

19. Shrestha K, Borowski AG, Troughton RW, et al: Association between systemic neutrophil gelatinase-associated lipocalin and anemia, relative hypochromia, and inflammation in chronic systolic heart failure. Congest Heart Fail 2012 Sep-Oct;18(5):239-44.

20.Isik T, Kurt M, Ayhan E, et al: Relation of red cell distribution width with presence and severity of coronary artery ectasia. Clin Appl Thromb Hemost 2012 Sep;18(5):441-7.

21. Sharp J, Farha S, Park MM, Comhair SA, Lundgrin EL, Tang WH, Bongard RD, Merker MP, Erzurum SC. Coenzyme Q supplementation in pulmonary arterial hypertension. Redox Biol 2014 Jul 31;2:884-91.

22. Bujak K, Wasilewski J, Osadnik T, Jonczyk S, Kołodziejska A, Gierlotka M, Gąsior M. The Prognostic Role of Red Blood Cell Distribution Width in Coronary Artery Disease: A Review of the Pathophysiology. Dis Markers 2015;2015:824624.

23. Malik A, Bissinger R, Liu G, Liu G, Lang F. Enhanced eryptosis following gramicidin exposure. Toxins (Basel) 2015 Apr 23;7(5):1396-410.

24.Dong X, Liao Y, Chen K, Fang Y, Li W, Chen J, You L, Li S. Elevated red blood cell distribution width in benign prostatic hyperplasia patients with metabolic syndrome. Int J Clin Exp Med 2015 Jan 15;8(1):1213-9.

25. Yilmaz Ö, Mehmet C, Kelekci S, Temur M. Association between red blood cell distribution width and polycystic ovary syndrome. Endocr Res 2015 Nov;40(4):181-7.

26. Dada OA, Uche E, Akinbami A, Odesanya M, JohnOlabode S, Adediran A, Oshinaike O, Ogbera AO, Okunoye O, Arogundade O, Aile K, Ekwere T. The relationship between red blood cell distribution width and blood pressure in patients with type 2 diabetes mellitus in Lagos, Nigeria. J Blood Med 2014 Sep 19;5:185-9.
27. Lorente L, Martín MM, Abreu-González P, SoléViolán J, Ferreres J, Labarta L, Díaz C, González O, García D, Jiménez A, Borreguero-León JM. Red blood cell distribution width during the first week is associated with severity and mortality in septic patients. PLoS One 2014 Aug 25;9(8):e105436.

28. Tosu AR, Demir S, Selcuk M, Kaya Y, Akyol A, Ozdemir M, Tenekecioglu E. Comparison of inflammatory markers in non-dipper hypertension vs. dipper hypertension and in normotensive individuals: uric acid, C-reactive protein and red blood cell distribution width readings. Postepy Kardiol Interwencyjnej 2014;10(2):98-103.

29. Tsuboi S, Miyauchi K, Kasai T, Ogita M, Dohi T, Miyazaki T, Yokoyama T, Kojima T, Yokoyama K, Kurata T, Daida H. Impact of red blood cell distribution width on long-term mortality in diabetic patients after percutaneous coronary intervention. Circ J 2013;77(2):456-61.

30. Roy CN, Semba RD, Sun K, Bandinelli S, Varadhan R, Patel KV, Guralnik JM, Ferrucci L. Circulating selenium and carboxymethyl-lysine, an advanced glycation endproduct, are independent predictors of anemia in older community-dwelling adults. Nutrition 2012 Jul;28(7-8):762-6.

31.Karakilcik AZ, Halat R, Zerin M, Celik H, Nazligul Y. Effects of vitamin $\mathrm{C}$ and exercise on lipid profile, platelet and erythrocyte indices in young soccer players. J Sports Med Phys Fitness 2014 Oct;54(5):665-71.

32. Ribeiro IF, Miranda-Vilela AL, Klautau-Guimarães Mde N, Grisolia CK. The influence of erythropoietin $(\mathrm{EPO} \mathrm{T} \rightarrow \mathrm{G}$ ) and $\alpha$-actinin-3 (ACTN3 $\mathrm{R} 577 \mathrm{X})$ polymorphisms on runners' responses to the dietary ingestion of antioxidant supplementation based on pequi oil (Caryocar brasiliense Camb.): a before-after study. J Nutrigenet Nutrigenomics 2013;6(6):283-304.

33. Prasad K. Effect of chronic administration of vitamin E on the hemopoietic system in hypercholesterolemia. Mol Cell Biochem 2010 Oct;343(1-2):67-73. 